\title{
The Role of Customers' Involvement in Value Co-creation Behaviour is Value Co-creation the Source of Competitive Advantage?
}

- Ercsey Ida

\begin{abstract}
According to service dominant logic (SDL), customers are always active participants and collaborative partners in exchanges; therefore we should focus on the elements of consumer behaviour that are connected with the value co-creation. By involving the customers in service production, providers can capture customers' needs and maintain their competitiveness. The cutomers' roles may lead to a higher productivity and competitive quality for companies. Previous researches recognized two types of the customers' co-creation behaviour. First, it is the consumers' participation behaviour. Then, the other one is the consumers' citizenship behaviour. The goal of our study is to examine how the level of involvement influences two kinds of behaviour mentioned. Besides, we explore if respondents' participation behaviour or citizenship behaviour influence the perceived value of service provided. In 2015, for examination of our research questions, we carried out a quantitative research and applied quota sampling to obtain data from two target groups ( $\mathrm{X}$ and $\mathrm{Y}$ generations). The activity and attitude of individuals related to performance of an extra-role in service interaction is less favourable than the required in-role behaviour. According to the results of our survey, the level of involvement influences the customers' mandatory behaviour and volunteer behaviour when working on a co-creation value. Empirically verifiable, the service users' activity in a value creation affects customers' value of the service.
\end{abstract}

Keywords: involvement, co-creation value, participation behaviour, citizenship behaviour, perceived value JEL Classification: M31

\section{INTRODUCTION}

In this century, lifestyle and the structure of consumption have changed, especially among younger generations. Service providers need to reach the competitive edge in order to retain their customers. Previous studies have shown that keeping a consumer can be up to ten times cheaper than attracting a new one. Therefore, companies have to make efforts to retain customers, attempting to minimise their migration. One strategy is co-creation, which means a mutual creation of value and experience, especially in case of leisure-time services. According to service dominant logic (SDL), the co-creation value is developed by a mutual activity of a consumer and a service provider through establishment of different sources. The concept of SDL places intangible resources, co-creation and relationships in the focus of marketing. A consumer activity during the process of co-creation value and support of the activity during the co-creation process enable service providers to fit their services to their consumers' needs. The result of value co-creation gives value for consumers as well as providers. 
Previous researches into co-creation focused on generic and industry specific (health, manufacturing, retail, and tourism, ) empirical studies (Oh \& Teo, 2010; Prebensen \& Foss, 2011; Gill, White $\&$ Cameron, 2011). The authors discussed the frameworks of co-creation from the encounters', suppliers' and customers' perspective. In general, customers' contributions and behaviour are distinguished (Hutter, Hautz, Fueller, Mueller \& Matzler, 2011). According to the authors' approach, other studies describe the attributes of co-creation from activities' perspective (Gebauer, Johnson \& Enquist, 2010), the customer (Tynan, McKechnie \& Chhuon, 2010), capability (Fujioka, 2009), experience (Gentile, Spiller \& Noci, 2007; Prahalad \& Ramaswamy, 2004), the roles (Andreu, Sánchez \& Mele, 2010; Grönroos, 2008), service (Vargo, Maglio \& Akaka, 2008), and the value (Ueda, Takenaka \& Fujita, 2008). Durugbo \& Pawar (2014) developed a unified model of cocreation that integrates the functions of a supplier and consumers' involvement based on existing value-in-exchange and value-in-use and in order to select co-creation techniques.

Throughout production of the service, depending on a type of services, the customers' participation roles can vary from low to high. In most cases, the customers' input forms the information and instruction needed for a service provider. Moreover, the service can not be created without a customer (Lovelock \& Wirtz, 2004). The customers' roles are various, e.g. a customer as the innovator - his or her ideas and knowledge contribute to new service; a customer as the source of competence, customers define an important value for themselves and co-create it (Prahalad \& Ramaswamy, 2000); a customer as the co-producer contributing to development of the service specification, quality control and marketing; a customer as the promoter of service provider who becomes a part of a customer-driven community by advocacy and WOM; a customer as the partial employee who performs tasks in service production.

Hungarian marketing literature lacks research regarding co-creation consumer behaviour of different services. This paper is a part of complex research topic, and we focus on antecedent and consequence of value co-creation behaviour. The authors examined relationship between the value of cultural activities and quality of life (Ercsey \& Józsa, 2015). Besides, we have defined the value dimensions of cultural services and now, we want to investigate value co-creation from the customers' perspective. The purpose of this article is twofold; first, to determine the effects of involvement in value co-creation behaviour. Second, the study aims to reveal association between the value co-creation behaviour and the perceived value. We formulated two research questions to investigate factors of customer participatory behaviour and customer citizenship behaviour in different service contexts. Our findings can be used for identification of the level of consumer co-creation and support of co-creation behaviour.

\section{LITERATURE REVIEW}

First, we gain an insight into the meaning and the role of involvement. Then, we include the consumers' activitites in value co-creation.

\subsection{Involvement and the role of customers}

According to the most used definition, involvement is " a person's perceived relevance of the object based on inherent needs, values and interest" (Zaichkowsky, 1985, 342. pp.). In consumer behaviour 
literature, three dimensions of involvement are distinct intensity, duration and orientation (Andrews, Durvasula \& Akhter, 1990). Duration of involvement is the basic aspect of differentiation between situational and enduring involvement. The enduring involvement is a relative standard impulse based on individual' experience and the importance of an object given stated. On the contrary, the situational involvement is short time, it can be recognized by stimulus, and in marketing, it was set as a state of impulse by certain buying situation. We can distinguish low and high involvement based on intensity, which is often mentioned by the respondents of the empirical research. The involvement provides more categories. Marketing researches emphasize product involvement, product-category involvement, brand involvement, and purchase involvement. Product decision (PDA) involvement as well as shopping involvement is in a process of examination of hedonic values. The scale for measurement of purchase involvement comprises dimensions of rational buying decision and also buying action with hedonic pleasure (Bergadaá, Faure \& Perrien, 1995). The dimensions of scale were developed by authors: social, economic, entertainment, disinterest. Besides, numerous studies point at the importance of the advertising involvement, focused on searching actively and process information provided of a shop assistant. In our research, we regard involvement as an interior readiness state that reflects the importance and relevance of objects to orientation we focus on the service group involvement.

Researches on consumer behaviour have revealed that involvement has influenced the purchase decisions. Zaichkowsky's (1994) Personal Involvement Inventory (PII) scale measures three dimensions of involvement: personal, physical and situational dimensions. Since earlier researches engaged in effect product selection and buying decision of involvement (Mittal \& Lee, 1989; Gyulavári \& Dörnyei, 2012). The revised PII scale identifies affective and cognitive dimensions which include five items for both dimensions (Zaichkowsky, 1994). The cognitive dimension comprises: important, relevant, valuable, means a lot to me, and needed. The affective dimension consists of: interesting, appealing, fascinating, exciting and involving. Bienstock and Stafford (2006) examined the applicability and validity of cognitive and affective involvement across a variety of services among American respondents. They investigated the services: hedonic vs. utilitarian, professional vs. retail, male- vs. female-dominated services. The empirical results verified a two-dimensional scale of involvement except "involving" which was dropped after the recognition of factors. The involvement towards seasonal services may occasionally be gaining ground, and then it may again moderate. These services can turn into the way of living and their involvement can intensify in the long-time perspective or on the contrary, since they provide less and less novelty, the individual meanwhile refers to other providers or services.

The results of researches confirm when experience is extremely important for the consumers then they tend to search more information about provider (Friedman \& Smith, 1993) more actively participate in production of service (Hollebeek, Jaeger, Brodie \& Balemi, 2007), and this amplifies the commitment to the evaluation after buying. The researches on the consequences of the service involvement focus on the information search strategies (Edgett \& Cullen, 1993), advertising (Stafford, 1996) and perceived quality (Shaffer \& Sherrel, 1997). 


\subsection{Value co-creation and consumer behaviour}

Co-creation has been defined in terms of co-creation of value (Prahalad \& Ramaswamy 2004; Vargo \& Lusch 2004). They state that co-created experience becomes an important basis of value. According to Service Dominant Logic (SDL), the customers are always active participants and collaborative partners in exchanges, customers co-create value with the firm (Vargo \& Lusch 2008). The value is determined in use through activities and interactions of customers with the service provider and other customers. Co-creators are those customers who are capable of applying their competencies providing the service for the benefit of other customers and themselves. These customers not only co-produce but also co-consume with firms and other customers.

In the marketing literature, little piece of papers investigated dimensions of the customer value co-creation behaviour. Previous authors used a multidimensional approach to explore the components of the customer value co-creation behaviour (Groth, 2005; Bove, Pervan, Beatty \& Shiu, 2008). Besides, other researchers apply a one-dimensional approach and use single- or multipleitem measures (Dellande, 2004; Fang, 2008). Yí \& Gong (2013) identified dimensions of the customers' behaviour in co-creating value, and developed a scale to measure it. The companies can use this scale to detect the weaknesses and strengths of the customer value co-creation behaviour.

Several studies have explored the nature and dimensions of the customer value co-creation behaviour. In a conceptual paper, the authors divide the value co-creation into six dimensions or types of actions performed by users and providers (Neghina, Caniëls, Bloemer \& Van Birgelen, 2014). Regarding the research paper, Randall, Gravier \& Prybutok (2011), Mc-Coll Kennedy, Vargo, Dagger, Sweeney \& Van Kasteren, (2012), Yi \& Gong (2013) and Chen \& Raab (2014) are particularly relevant. The first study (Randall, Gravier \& Prybutok, 2011) proposes the construction of a measurement scale composed of three dimensions: connection, trust and commitment. The authors used a mixed method, the combination of qualitative (in-depth interviews) and quantitative (survey) analysis techniques for examination of customer relationship management. In the second work, Mc-Coll Kennedy, Vargo, Dagger, Sweeney \& Van Kasteren, (2012) divided the construct into eight activities, pinpointing different types of the value co-creation practices in terms of activities and interactions actually accomplished by users not only in the moment of interaction with employees. The researchers identified eight value co-creation activities: cooperating, collating information, combining complementary therapies, co-learning, and changing ways of doing things, connecting, coproduction and cerebral activities. However, they did not semantically analyse the differences between dimensions, but merely present examples derived from respondents' answers. It is proposed that the customer value co-creation behaviour has a hierarchical-factor structure, which in turn can be divided into several sub-dimensions: cognitive activities, cooperation, information research and collation, combination of complementary activities, changing habits, co-production, co-learning and connection.

Yi \& Gong (2013) applied a third-order factor through the lens of two theories: customer participation behaviour and customer citizenship behaviour, related respectively to the concepts of in-role behaviour and extra-role behaviour. The customer participation behaviour belongs to the required behaviour which is necessary for a successful value co-creation. The customer citizenship behaviour is voluntary behaviour that provides an extraordinary value to the firm but is not 
necessarily required for the value co-creation (Groth, 2005; Bove, Pervan, Beatty \& Shiu, 2008; Yi, Nataraajan \& Gong, 2011). The empirical results show that in-role and extra-role behaviours follow different patterns and have different antecedents and consequences (Groth, 2005; Yi, Nataraajan \& Gong, 2011). Yi \& Gong (2013) conceptualized the customer value co-creation behaviour as a multidimensional concept which consists of two factors (customer participation behaviour and customer citizenship behaviour), and each factor contains multiple dimensions. The customer participation behaviour comprises four dimensions: information seeking, information sharing, responsible behaviour, and personal interaction. Besides, the customer citizenship behaviour consists of feedback, advocacy, helping, and tolerance. Finally, Chen \& Raab (2014) developed and validated the mandatory customer participation (MCP) scale which was applied for Engel-Blackwell-Kollat model. This scale can be divided into three dimensions: information participation, attitudinal participation, actionable participation. This research evaluated how the intrinsic antecedents as role clarity, self-efficacy, and purchase importance could influence MCP. Besides, the authors tested the relationship between one extrinsic antecedent, serviscape and the participation behaviour. The authors applied this scale to investigate the consumer decision process related to the restaurant service.

\section{METHODOLOGY}

In our empirical research, we focused on examination of the level of voluntary and non-voluntary co-creation behaviour in terms of different services. Moreover, we investigated the effect of involvement on customers' activities.

Involvement influences not only buying decisions but also the customer participation in service production and consumption. Consequently, we observed the effect of involvement on customer value co-creration behaviour. First, the research question and hypothesis:

RQ1: How does involvement influence the customer participation and citizenship behaviour?

H1: Involvement has a direct positive impact on the customer participation and citizenship behaviour.

More papers on value co-creation have explored the association between the customer value dimensions and the customer activities. Based on these, we point out the need for studying relationship between the customer participation, citizenship behaviour and the perceived value. Thus, based on the second research question, we hypothesise:

RQ2: What is the relationship between the participation behaviour, citizenship behaviour and the perceived value?

H2: The participation behaviour as well as the citizenship behaviour has a direct positive effect on the perceived value.

The research model showing two hypotheses is represented in Figure 1. 


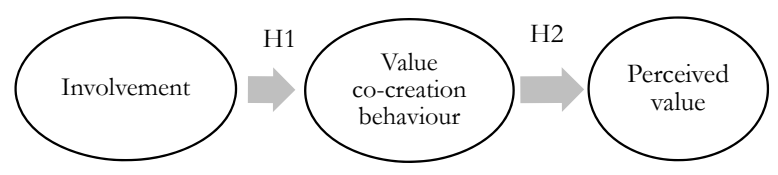

Fig. 1 - Research model Source: own compilation

Besides, we want to explore the generation differences in co-creation value customer behaviour.

For the purpose of our research, we worked on a survey last year in April and May. The target group of our quantitative research are two segments which can be divided by age, family and occupational status: Y and X generation. The consumption preferences of members of Millennial generation, especially students, are meaningful as a research topic in the domestic as well as international contexts. We applied a quota sampling method, using quotas for ages and gender. The sample size is 335 persons, 57 percent of them are between the age of 18-26, and the other part belongs to X generation. $40 \%$ of respondents are women and $60 \%$ are men. Twenty three percent of respondents live in county towns where more kinds of services are provided than in other cities (46\%) or villages (31\%). The composition of the sample is based on age: the rate of 18-26 age category is 57 percent (192 persons), and the rate of elder persons is 43 percent (143 persons).

\section{RESULTS}

We discuss the empirical research results by having the hypotheses in two subchapters.

\subsection{Testing $\mathrm{H} 1$ hypothesis}

For the first research question, we consider the role of involvement. Regarding involvement, we measured the attitude to services and a service provider with six items based on the literature (on a five-point scale). We applied the scale items of PII, and purchase involvement for studying the service involvement according to the expert and consumers' judgment. Our results show that there is an association between the importance of service and choosing the provider of it. We proved relationship regarding further scale items of involvement, such as "using service as entertainment", and "meeting people". We found out the following results after control of preconditions (outliers, normality). The KMO (0.695) and Bartlett test (278.583, Sig. = $0.000)$ indicate that the data is suitable for a factor analysis. We revealed two factors by applying the Principal components analysis and Varimax rotation method. The cumulative percentage of the variance explained by extracted factors is $63.858 \%$, which is above the expected level $(60 \%)$. The importance of service and its provider and the role of service in lifestyle can be distinguished within the cognitive dimension. The social dimension contains feelings, moods related to the service used, which is connected with respondents' entertainment and their social life. The results of this analysis are presented in Table 1. 
Tab. 1 - Factors of involvement Source: own compilation

\begin{tabular}{|c|c|c|}
\hline Variables of involvement & $\begin{array}{l}\text { Factors } \\
\text { loadings }\end{array}$ & $\begin{array}{l}\text { Factors } \\
\text { explained variance }\end{array}$ \\
\hline In my every-day life, the service is important & 0.796 & \multirow{4}{*}{$\begin{array}{c}\text { Cognitive involvement } \\
32.858 \%\end{array}$} \\
\hline $\begin{array}{l}\text { It is important for me to use service of the same pro- } \\
\text { vider }\end{array}$ & 0.710 & \\
\hline Service is very important & 0.651 & \\
\hline Service is not relevant to me & -0.469 & \\
\hline Using service is entertaining & 0.827 & \multirow{2}{*}{$\begin{array}{l}\text { Social involvement } \\
\quad 31.000 \%\end{array}$} \\
\hline Using service is an opportunity for me to meet people & 0.783 & \\
\hline
\end{tabular}

First, we explore what is the level of involvement of last service used by respondents. We computed the mean scores for factors based on the variables of two factors, and the results indicate that the level of social involvement is higher (mean=4.05) than cognitive involvement (mean=3.33). When studying involvement, the respondents'opinion does not result in significant variance, standard deviation of social involvement is 0.958 , and it is 0.801 in case of cognitive involvement. Dispersion of the cognitive involvement factor is shown in Figure 2. The skewness (0.051) and curtosis (-0.420) score of cognitive factor confirm that the difference from a normal distribution is not significant.

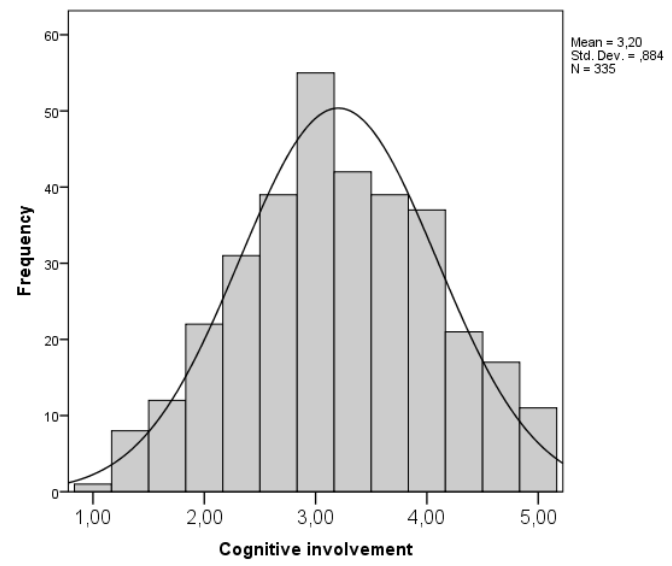

Fig. 2 - Distribution of a cognitive involvement factor Source: own compilation

The social involvement resulted in better values, when the mean score is 4.05 , and dispersion from the mean (0.951) is not high. Figure 3 presents dispersion of the social involvement factor. In this histogram, a smooth line shows that distribution of social involvement is skewed to the left, and curtosis is higher. Therefore, there is deviation from a normal distribution. 


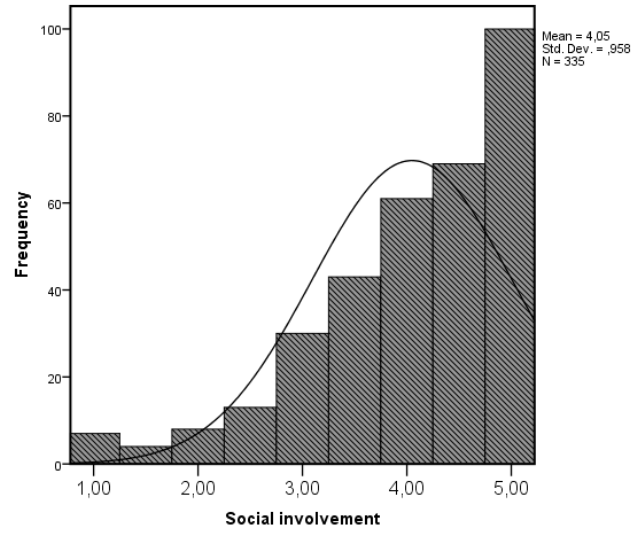

Fig. 3 - Distribution of a social involvement factor Source: own compilation

Second, we investigated how the level of involvement influences the respondents' participation and citizenship behaviour. For the examination of our research questions, first we adopted a previous scale (Yi \& Gong 2013) to measure the co-creative customers' behaviour. Our decision was confirmed by adaptation of the scale in Spain and its results (Revilla-Camacho, Vega, Vázquez $\&$ Cossio-Silva, 2015). The service selected for testing the hypotheses was the leisure activities, which represent an incresing trend for years in Hungary. Besides, we focused on service settings in service interactions of the customers, personnel and other customers meeting face-to-face. We asked respondents to evaluate their last services used to investigate the customers' co-creation behaviour. A notable part of young respondents participated in cultural activities $(28 \%$, theatre, movie, interactive museum, festival), went to use a wellness service (42\%, fitness, spa, hairdresser) and hospitality service (30\%, restaurant).

In order to recognize dimensions of customer participation behaviour, we measured it by using 15 items (on a five-point scale) according to a validated scale (Yi \& Gong 2013). An exploratory factor analysis was carried out, focusing on the customer value co-creation activities to recognize dimensions of the customer participation behaviour. The original 15 items are appropriate for measurement of the individuals' role to perform the service. Information seeking and information sharing can be distinguished within the customer participation behaviour similarly to previous pieces of research on services. However, the elements of responsible behaviour and the personal interaction constitute one factor. These results are inconsistent with a previous research (Yi \& Gong 2013; Revilla-Camacho, Vega, Vázquez \& Cossio-Silva, 2015) because English and Spanish respondents made a distinction between the factors of personal interaction and responsible behaviour. The items of customers' responsible behaviour emerge in interaction between the personnel and customer and they are necessary to produce a successful service expected by customers. This factor together with a personal interaction includes the respondents' attitude and behaviour to the personnel and provider. We summarized the factor analysis' result in Figure 4. As we expected, in the customer participation behaviour, we can differentiate the information sharing, information seeking, and the personal interaction-responsible behaviour dimensions, three distinct dimensions can be recognised in co-creation of cultural, wellness and hospitality services. 


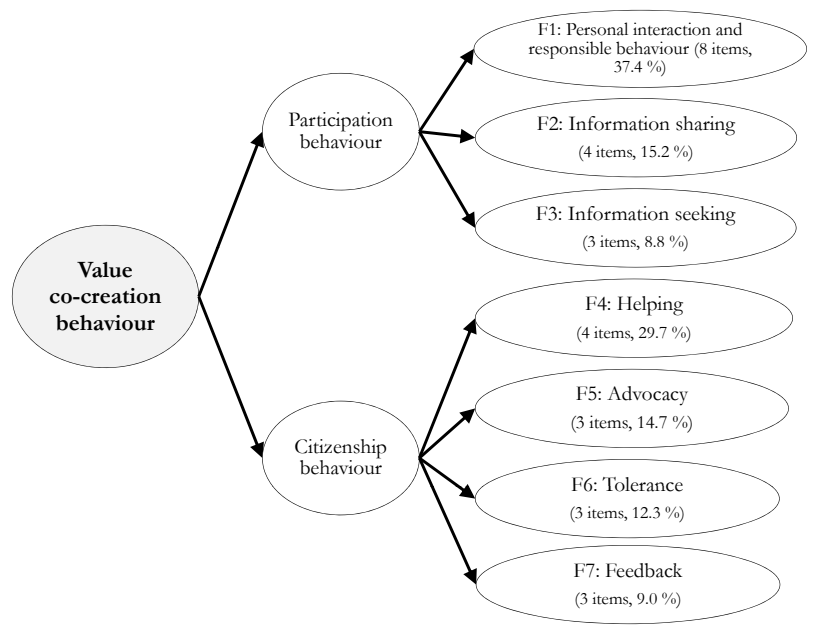

Fig. 4 - Dimensions of co-creation behaviour Source: own compilation

In order to identify dimensions of customer citizenship behaviour, we measured it by using 13 items (on a five-point scale) according to the validated scale (Yi \& Gong 2013). An exploratory factor analysis was carried out, focusing on the customer value co-creation activities to recognize dimensions of the customer participation behaviour. The original 13 items are appropriate for measurement of the individuals' extra role performing the service. Helping, advocacy, tolerance and feedback can be distinguished within the customer voluntary behaviour similarly to previous pieces of research about services. Our result corresponds to the numbers and names of factors in previous studies. These factors imply an extra value to the provider in case of customer'active behaviour. Two factors of the recognized ones, tolerance and feedback, emerge in relationship between the respondents and personnel. The other factors, helping and advocacy, are appeared in transaction between the respondents and other customers. We summarized the factor analysis' results in Figure 4. The respondents' positive attitude to personnel through tolerance and feedback is not significant. As we expected, in the customer citizenship behaviour, we can differentiate helping, advocacy, tolerance and feedback dimensions, four behavioural dimensions can be recognised in co-creation of cultural, wellness and hospitality services. The items and statistical coefficitents to factors of participation and citizenship behaviour were presented by authors in the article (Ercsey, 2015).

First, we give an overview of factors based on descriptive statistics. We counted the overage value of the factor using the variables to the given factor. Our results show that service users perform more in-role behaviours, especially activities of a personal interaction and responsible behavior. We measured variables on five-point scales and the ranges of five factors (F1, F2, F4, F6 and F7) are four, these data are consistent. Merely two factors resulted in a lower value. In case of information seeking (F3), most of respondents' attitude is unfavourable, but their advocacy (F5) is the most favourable dimension within extra-role behaviour. A standard deviation of factors is not high, from 0.58 to 1.05 . Figure 5 presents results of descriptive statistics for the factors. 


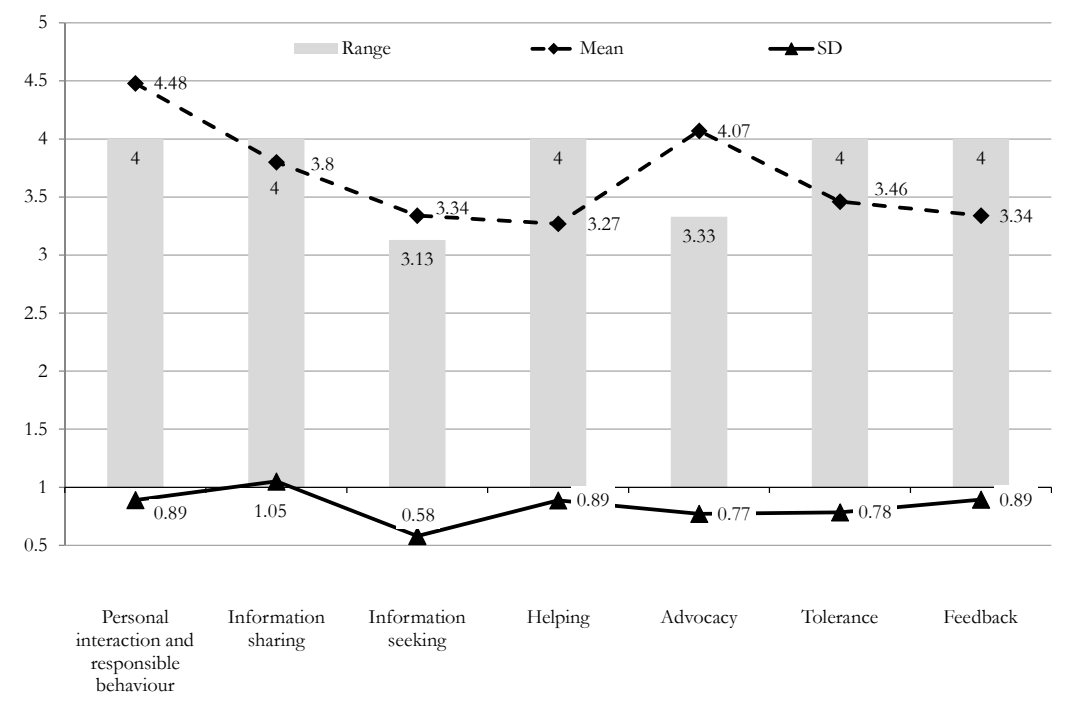

Fig. 5 - Descriptive statistics of the factors - customers'participation and citizenship behaviour Source: own compilation

We assumed that a generation gap exists between cooperation skills of the service production. Our results show that $\mathrm{X}$ and $\mathrm{Y}$ generations have differed significantly in seeking information, information sharing and feedback. The members of $\mathrm{Y}$ generation use preferably non-personal sources for information seeking to cultural or wellness services used. However, the elder consumers prefer a direct personal contact to gain information. In addition, information seeking plays a greater role for $\mathrm{X}$ generation than the younger ones. Furthermore, the elder persons are open-minded when communicating with a service provider. We revealed congruently high scores for evaluation of a personal interaction and responsible behaviour. The feedback about consumers' experience is not typical, but $\mathrm{X}$ generation gives more notions of it. Both two age groups provide a positive feedback about the service used than negative one.

We made a multivariate regression analysis using two involvement factors as independent variables and the factors of consumer participation and citizenship behaviour as dependent variables for testing the hypothesis 1 . According to the results of the regression analysis, the level of involvement is significantly positively related to two dimensions of consumers' participation behaviour and three factors of citizenship behaviour (Table 2 and 3). The results of the multiple regression analysis show that the variation explained in consumers' participation behaviour by the factors of involvement is not high, the coefficients of multiple determinations are $\mathrm{R}^{2}=7.7$ $\%(\mathrm{~F}=13.770$, Sig. $=0.000)$, and $\mathrm{R}^{2}=7.6 \%(\mathrm{~F}=13.738$, Sig. $=0.000)$. For the regression results presented in Table 2 , the variation of social involvement in personal interaction and responsible behavior is higher $(\beta=0.223)$ than it is in case of the cognitive involvement $(\beta=0.164)$. The social involvement factor is associated with the other factor of mandatory behaviour, the consumers' information seeking. Furthermore, the positive sign of beta coefficient $(\beta=0.266)$ implies a positive linear relationship. 
Tab. 2 - Relationship between involvement and customers' participation behaviour Source: own compilation

\begin{tabular}{|l|c|c|c|}
\hline Multiple Regression & $\beta$ & $\mathrm{t}$ & Sig. \\
\hline $\begin{array}{l}\text { F1 Cognitive involvement } \rightarrow \text { F1 Personal interaction and } \\
\text { responsible behaviour }\end{array}$ & 0.164 & 0.164 \\
\hline $\begin{array}{l}\text { F2 Social involvement } \rightarrow \text { F1 Personal interaction and respon- } \\
\text { sible behaviour }\end{array}$ & 0.223 & 4.232 & 0.000 \\
\hline R2 $=0.077$ F $=13.770 ;$ Sig. $=0.000$ & 0.266 & 5.045 & 0.000 \\
\hline F1 Cognitive involvement $\rightarrow$ F3 Information seeking & \multicolumn{3}{|l|}{} \\
\hline R2 $=0.076 ;$ F $=13.738 ;$ Sig. $=0.000$ &
\end{tabular}

We revealed that the variation of the involvement factors in the consumers'voluntary behaviour is relatively low. These data are as follows: $\mathrm{R}^{2}=9.1 \%(\mathrm{~F}=16.652$, Sig. $=0.000), \mathrm{R}^{2}=11.1 \%$ $(\mathrm{F}=20.688$, Sig. $=0.000)$, and $\mathrm{R}^{2}=3.6 \%(\mathrm{~F}=6.161$, Sig. $=0.002)$. However, regarding the consumers' behaviour, the cognitive elements of involvement, such as the importance of service and provider, is more relevant for users. Our results show that there is a significant positive effect of the cognitive involvement on helping other users $(\beta=0.302)$ and on a positive or negative feedback toward the provider $(\beta=0.188)$. Finally, the results indicate the social involvement $(\beta=0.248)$ and cognitive involvement $(\beta=0.223)$, and also a positive influence on the consumers'advocacy toward other consumers atttached to the service company and personnel (Table 3).

Tab. 3 - Relationship between involvement and customers' citizenship behaviour Source: own compilation

\begin{tabular}{|c|c|c|c|}
\hline Multiple Regression & $\beta$ & $\mathrm{t}$ & Sig. \\
\hline F1 Cognitive involvement $\rightarrow$ F4 Helping & 0.302 & 5.768 & 0.000 \\
\hline \multicolumn{4}{|l|}{$\mathrm{R}^{2}=0.091 ; \mathrm{F}=16.652 ;$ Sig. $=0.000$} \\
\hline F1 Cognitive involvement $\rightarrow$ F5 Advocacy & 0.223 & 4.300 & 0.000 \\
\hline F2 Social involvement $\rightarrow$ F5 Advocacy & 0.248 & 4.748 & 0.000 \\
\hline \multicolumn{4}{|l|}{$\mathrm{R}^{2}=0.111 ; \mathrm{F}=20.688 ;$ Sig. $=0.000$} \\
\hline F1 Cognitive involvement $\rightarrow$ F7 Feedback & 0.188 & 3.480 & 0.001 \\
\hline $\mathrm{R}^{2}=0.036 ; \mathrm{F}=6.161 ;$ Sig. $=0.002$ & & & \\
\hline
\end{tabular}

Our assumption partly verified the level of involvement and that it influences positively five dimensions of the consumers' participation and citizenship behaviour, H2 hypothesis is partly accepted.

\subsection{Testing $\mathrm{H} 2$ hypothesis}

To examine dimensions of value co-creation behaviour, we suppose that the factors of participation and citizenship behaviour have positive effects on the evaluation of service value. For evaluation of the service by a consumer in order to measure the overall perceived value, we applied two-item scale ("Regarding what I received and gave my opinion, it is positive", "It met my demand and exceptations,"). An exploratory factor analysis was carried out, focusing on the perceived customer value, 
to recognize the value dimension of the services used. We found one factor by applying the Principal components analysis and the Varimax rotation method. First, we examined the association between the three factors of the participation behaviour as independent variables and the overall perceived value as a dependent variable. According to the regression analysis, the explanation force of Factor 1 (personal interaction and responsible behaviour) is $28 \%\left(\mathrm{R}^{2}=0.280\right)$ in the service value used. Based on the figures of Table 4, we can determine that information sharing and information seeking belonging to the participation behaviour do not have a significant impact on the overall evaluation of services.

Tab. 4 - Relationship between the factors of customers' participation behaviour and the perceived value Source: own compilation

\begin{tabular}{|l|r|r|c|}
\hline Factors of customers' participation behaviour $\rightarrow$ Perceived value & $\beta$ & $\mathrm{t}$ & Sig. \\
\hline F1 Personal interaction and responsible behaviour & 0.526 & 11.194 & 0.000 \\
\hline F2 Information sharing & 0.029 & 0.613 & 0.541 \\
\hline F3 Information seeking & 0.055 & 1.172 & 0.242 \\
\hline $\mathrm{R}^{2}=0.280 ; \mathrm{F}=42.349 ;$ Sig. $=0.000$ & \\
\hline
\end{tabular}

Following the research protocol, we investigated relationship between four factors of the citizenship behaviour as independent variables and the overall perceived value as a dependent variable. According to the results of the regression analysis, we conclude that within the voluntary behaviour principally the advocacy (F5), the tolerance (F6) and the feedback (F7) explain (R2 $=0.310)$ the perceived value of the service used. The figures of Table 5 justify that from dimensions of the citizenship behaviour, helping other consumers (F4) does not have a significant impact on the overall evaluation of the services.

Tab. 5 - Relationship between the factors of customers' citizenship behaviour and the perceived value Source: own compilation

\begin{tabular}{|l|r|r|c|}
\hline Factors of customers' citizenship behaviour $\rightarrow$ Perceived value & $\beta$ & \multicolumn{1}{c|}{$\mathrm{t}$} & Sig. \\
\hline F4 Helping & -0.020 & -0.425 & 0.671 \\
\hline F5 Advocacy & 0.454 & 9.806 & 0.000 \\
\hline F6 Tolerance & 0.275 & 5.937 & 0.000 \\
\hline F7 Feedback & 0.166 & 3.591 & 0.000 \\
\hline $\mathrm{R}^{2}=0.310 ; \mathrm{F}=36.121 ;$ Sig. $=0.000$ & \multicolumn{4}{|l}{} \\
\hline
\end{tabular}

H2 can be partly verified: in the evaluation of the service value, four factors of participation behaviour and citizenship behaviour give a moderate explanation force.

Our expectation is verified, the personal interaction between the consumers and the personnel and the consumers' responsible behaviour attached to the performing service have a positive impact on the service value. However, there is no significant association between the consumers' information seeking, the information sharing to the personnel and the perceived value of service. Finally, the consumers' activities in advocacy, besides the tolerance and feedback attached, show a positive association with the service value. 


\section{DISCUSSION AND CONCLUSIONS}

Our results show that customers' feeling for co-creation can be examined with a multi-dimensions construct. The activity and attitude of individuals related to performing an extra-role in service interaction is less favourable than the required in-role behaviour. We conclude that value co-creation not only refers to co-production through the company-customer interaction but also the co-creation of value through customer-to-customer interaction.

According to our findings, the level of involvement is associated with the information searching of the consumers which can be used for an advertising strategy of the company. Major contribution is the exploration of the level and nature of the cognitive and affective involvement. We highlighted that the social involvement related to the cultural services resulted in higher involvement. Therefore, the managers would emphasize the affective elements in communication.

Yi \& Gong (2013) confirmed that the consumers' participation behaviour influences the perceived value of service used by consumers $(\beta=0.39)$. Furthermore, the consumers' citizenship behaviour has a positive significant impact on the consumer value $(\beta=0.31)$. The importance of purchase from intrinsic factors which influence the consumers' mandatory participation was examined in case of restaurant service and the authors found a direct positive impact on the information $(\beta=0.16)$ and actionable $(\beta=0.17)$ participation (Chen $\&$ Raab, 2014). This result is consistent with the statement that the purchase involvement of the consumers motivates to have further information searching and more active participation in service production (Hollebeek, Jaeger, Brodie, \& Balemi, 2007).

An additional research with other generations could provide an valuable insight into dimensionality of a customer participation. Another interesting area for further studies would be extending to other service domains, such as healthy lifestyle services (Keller, \& Dernóczy-Polyák, 2015).

It would be very useful to pay more attention to the characteristics of co-creative customers. Furthermore, managers should know that customers who are intensely involved with their service experience assign a greater importance to their service purchase. In addition, managers should be aware of how their customers obtain information about their service settings so as to manage the firms' external communications effectively. This finding can be valuable for managing firms' marketing communications by delivering the right amount of information to the right customer.

\section{Acknowledgment}

The research was funded by the following project: “EFOP-3.6.1-16-2016-00017; „Internationalisation, initiatives to establish a new source of researchers and graduates, and development of knowledge and technological transfer as instruments of intelligent specialisations at Széchenyi István University.”

\section{References}

1. Andreu, L., Sánchez, I., \& Mele, C. (2010). Value co-creation among retailers and consumers: New insights into the furniture market. Journal of Retailing and Consumer Services, 17(4), 241-250. doi:10.1016/j.jretconser.2010.02.001.

2. Andrews, J. C., Durvasula, S., \& Akhter, S.H. (1990). A framework for conceptualizing and measuring the involvement construct in advertising research. Journal of Advertising, 19(4), 27-40. http://dx.doi.org/10.1080/00913367.1990.10673198.

3. Bergadaá, M., Faure, C., \& Perrien, J. (1995). Enduring involvement with shopping. Journal of Social Psychology, 13(5), 17-25. http://dx.doi.org/10.1080/00224545.1995.9711396. 
4. Bienstock, C., \& Stafford, M.R. (2006). Measuring involvement with the service: A further investigation of scale validity and dimensionality. Journal of Marketing Theory and Practice, 14(3), 209-221. DOI 10.2753/MTP1069-6679140303

5. Bove, L. L., Pervan, S. J., Beatty, S. E. \& Shiu, E. (2008). Service worker role in encouraging customer organizational citizenship behaviours. Journal of Business Research. 62(1), 698-705. doi:10.1016/j.jbusres.2008.07.003.

6. Chen, S. C., \& Raab, C. (2014). Construction and validation of the customer participation scale. Journal of Hospitality Tourism Research, 46(1), 65-75. http://dx.doi.org/10.1016/ j.ijhm.2015.01.012.

7. Dellande, S., Gilly, M. C., \& Graham, J. L. (2004). Gaining compliance and losing weight: The role of the service provider in health care services. Journal of Marketing, 68(1), 78-91. DOI: $10.1177 / 1094670512442806$.

8. Durugbo, C. \& Pawar, K. (2014). A unified model of the co-creation process. Expert Systems with Applications, 41(9), 4373-4387. DOI: 10.1016/j.eswa.2014.01.007.

9. Edgett, S. J., \& Cullen, C. W. (1993). Service organization selection: a cross-cultural analysis of the role of involvement. European Journal of Marketing. 27(2), 33-45. http://dx.doi. org/10.1108/03090569310026844.

10. Ercsey, I. (2015). Value co-creation relating to cultural and health services. Tér-GazdaságEmber. 3(4) 47-61. http://kgk.sze.hu/images/dokumentumok/folyoirat/TGE_III_ evf04angol.pdf

11. Ercsey, I. \& Józsa, L. (2015). The effect of the perceived value of cultural services on the quality of life. International Review on Public and Nonprofit Marketing, 12(2), 22. DOI 10.1007/ s12208-015-0140-9.

12. Fang, E., Palmatier, R.W. \& Evans, K.R. (2008). Influence of Customer Participation on Creating and Sharing New Product Value. Journal of the Academy of Marketing Science, 36(3), 322-336. DOI: 10.1007/s11747-007-0082-9.

13. Friedman, L. M. \& Smith, L. J. (1993). Consumer evaluation processes in a service letting. Journal of Service Marketing. 7(2), 47-61. http://dx.doi.org/10.1108/08876049310038409

14. Fujioka, Y. (2009). A consideration of the process of co-creation of value with customers. Artificial Life and Robotics, 14(1), 101-103. DOI: 10.1007/s10015-009-0732-8.

15. Gebauer, H., Johnson, M., \& Enquist, B. (2010). Value co-creation as a determinant of success in public transport services: A study of the Swiss Federal Railway operator (SBB). Managing Service Quality, 20(6), 511-530. http://dx.doi.org/10.1108/09604521011092866.

16. Gentile, C., Spiller, N., \& Noci, G. (2007). How to sustain the customer experience: An overview of experience components that co-create value with the customer. European Management Journal, 25(5), 395-410. http://dx.doi.org/10.1016/j.emj.2007.08.005.

17. Gill, L., White, L., \& Cameron, I. D. (2011). Service co-creation in community-based aged healthcare. Managing Service Quality, 21(2). 152-177. http://dx.doi.org/10.1108/096045211111 13447.

18. Groth, M. (2005). Customers as good soldiers: Examining citizenship behaviours in internet service deliveries. Journal of Management, 31(1), 7-27. DOI: 10.1177/0149206304271375. 
19. Grönroos, C. (2008). Service logic revisited: Who creates value? And who cocreates? European Business Review, 20(4). 298-314. http://dx.doi.org/10.1108/09555340810886585.

20. Gyulavári T., \& Dörnyei K. (2012). Az involvement lojalitásra gyakorolt hatásának vizsgálata, különös tekintettel az észlelt kockázat és tudás közvetítő hatására. Marketing \&Menedzsment, 46(1-2), 64-76. https://www.researchgate.net/publication/286976086.

21. Hollebeek, L. D., Jaeger, S. R., Brodie, R. J. \& Balemi, A. (2007). The influence of involvement on purchase intention for new world wine. Food Quality and Preference. 18(8), 1033-1049. doi:10.1016/j.foodqual.2007.04.007.

22. Hutter, K., Hautz, J., Fueller, J., Mueller, J., \& Matzler, K. (2011). Communitition: The tension between competition and collaboration in community-based design contests. Creativity and Innovation Management, 20(1), 3-21. DOI: 10.1111/j.1467-8691.2011.00589.x

23. Keller, V., \& Dernóczy-Polyák, A. (2015): Sustainable health - emotional eating or cognitive control? Tér, Gazdaság, Ember, 4(3), 63-90. http://kgk.sze.hu/images/ dokumentumok/folyoirat/TGE_III_evf04angol.pdf

24. Lovelock, C., \&Wirtz, W. (2004). Service Marketing: People, Technology, Strategy, 5th ed., Pearson Prentice-Hall, Upper Saddle River, NJ. http://trove.nla.gov.au/work/7261351.

25. McColl-Kennedy, J. R., Vargo, S. L., Dagger, T. S., Sweeney, J. C., \& Van Kasteren, J. (2012). Health Care Customer Value Cocreation Practice Styles. Journal of Service Research, 15(4), 370-389. DOI: 10.1177/1094670512442806.

26. Mittal, B., \& Lee, M. (1989). A causal model of consumer involvement. Journal of Economic Psychology, 10(3), 363-89. http://dx.doi.org/10.1016/0167-4870(89)90030-5.

27. Neghina C., Caniëls M. C. J., Bloemer J. M. M., \& Van Birgelen M. J. H. (2014). Value cocreation in service interactions: Dimensions and antecedents. Marketing Theory, 15(2), 1-22. doi: $10.1177 / 1470593114552580$.

28. Oh, L. B. \& Teo, H. H. (2010): Consumer value co-creation in a hybrid commerce servicedelivery system. International Journal of Electronic Commerce. 14(3). 35-62. DOI: 10.2753/ JEC1086-4415140303.

29. Prahalad, C. K. \& Ramaswamy, V. (2004). Co-creation experiences: The next practice in value creation. Journal of Interactive Marketing, 18(3). 5-14. DOI: 10.1002/dir.20015.

30. Prahalad, C.K., \& Ramaswamy, V. (2000). Co-opting customer experience. Harvard Business Review, 78(1), 79-87. R00108-PDF-ENG .

31. Prebensen, N. K. \& Foss, L. (2011). Coping and co-creating in tourist experiences. International Journal of Tourism Research. 13(1). 54-67. DOI: 10.1002/jtr.799.

32. Randall, W. S., Gravier, M. J., \& Prybutok, V. R. (2011). Connection, trust, and commitment: dimensions of co-creation? Journal of Strategic Marketing, 19(1), 3-24. DOI:10.1080/0965254X.2010.537760.

33. Revilla-Camacho, M. A., Vega, Vázquez, M., \& Cossio-Silva, F. J. (2015). Customer participation and citizenship behaviour effects on turnover intention. Journal of Business Research, 68(7), 1607-1611. 10.1016/j.jbusres.2015.02.004. 
34. Shaffer, T. R. \& Sherrell, D. L. (1997). Consumer satisfaction with health-care services: The influence of involvement. Psychology \& Marketing. 14(3) 261-285. DOI: 10.1002/(SICI)1520-6793(199705)14:3<261::AID-MAR4>3.0.CO;2-9

35. Stafford, M. R. (1996). Tangibility in Services Advertising: An Investigation of Verbal versus Visual Cues. Journal of Advertising. 25(3), 13-28. http://dx.doi.org/10.1080/00913367.1 996.10673504.

36. Tynan, C., McKechnie, S., \& Chhuon, C. (2010). Co-creating value for luxury brands. Journal of Business Research, 63(11), 1156-1163. http://dx.doi.org/10.1016/j.jbusres.2009.10.012.

37. Ueda, K., Takenaka, T., \& Fujita, K. (2008). Toward value co-creation in manufacturing and servicing. CIRP, Journal of Manufacturing Science and Technology, 1(1), 53-58. http://dx.doi. org/10.1016/j.cirpj.2008.06.007.

38. Vargo, S. L. \& Lusch, R. F. (2004). Evolving to a new dominant logic for marketing. Journal of Marketing, 68(1), 1-17. doi: 10.1509/jmkg.68.1.1.24036.

39. Vargo, S. L. \& Lusch, R. F. (2008). Service-Dominant Logic: Continuing the Evolution. Journal of the Academy of Marketing Science, 36(1), 1-10. DOI: 10.1007/s11747-007-0069-6.

40. Vargo, S. L., Maglio, P. P., \& Akaka, M. A. (2008). On value and value co-creation: A service systems and service logic perspective. European Management Journal, 26(3), 145-152. doi:10.1016/j.emj.2008.04.003.

41. Yi, Y. \& Gong, T. (2013). Customer value co-creation behavior: scale development and validation. Journal of Business Research. 66(9), 1279-1284. http://dx.doi.org/10.1016/ j.jbusres.2012.02.026.

42. Yi, Y., Nataraajan, R. \& Gong, T. (2011). Customer participation and citizenship behavioural influences on employee performance, satisfaction, commitment, and turnover intention. Journal of Business Research. 64(1), 87-95. DOI: 10.1016/j.jbusres.2009.12.007.

43. Zaichkowsky, J. L. (1985). Measuring the involvement construct. Journal of Consumer Research, 12(3), 341-52. http://dx.doi.org/10.1086/208520.

44. Zaichkowsky, J. L. (1994). The personal involvement inventory: Reduction, revision, and application to advertising. Journal of Advertising. 23(4), 59-70. http://dx.doi.org/10.1080/009 13367.1986.10672999.

\section{Contact information}

Ida Ercsey PhD Associate Professor

Széchenyi István University, Kautz Gyula Economics Faculty

9026. Györ, Egyetem tér 1, Hungary

Email:ercsey@sze.hu 